\title{
Development and Evaluation of Herbal Sunscreen
}

\author{
Mukund Manikrao Donglikar ${ }^{1}$ and Sharada Laxman Deore ${ }^{2^{*}}$
}

\section{Mukund Manikrao Donglikar ${ }^{1}$ and Sharada Laxman Deore ${ }^{2^{*}}$}

'Department of Pharmaceutical Sciences, Shri Jagdish Prasad Jhabarmal Tibrewala University, Vidyanagari, Jhunjhunu, Rajasthan-333001, INDIA. ${ }^{2}$ Department of Pharmacognosy and Phytochemistry, Government College of Pharmacy, Amravati-444604, Maharashtra, INDIA.

\section{Correspondence}

Sharada Laxman Deore, Department of Pharmacognosy and Phytochemistry, Government College of Pharmacy, Amravati-444604, Maharashtra, INDIA.

Phone no: 91-9766577646

E-mail: sharudeore_2@yahoo.com History

- Submission Date: 10-08-2016;

- Review completed: 22-09-2016;

- Accepted Date: 01-11-2016

\section{DOI : 10.5530/pj.2017.1.15}

Article Available online

http://www.phcogj.com/v9/i1

\section{Copyright}

(C) 2016 Phcog.Net. This is an openaccess article distributed under the terms of the Creative Commons Attribution 4.0 International license.

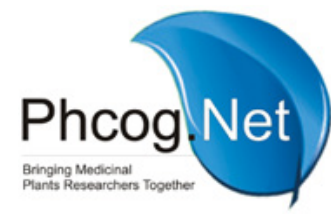

\begin{abstract}
Thus present research work deals with the development and evaluation of topical photo protective formulation, containing antioxidant, wound healing, anti-inflammatory and rather photo protective poly phenols like curcumin, quercetin, resveratrol and safranal. The present research work provides stable natural photo protective formulation with antioxidant potential, high SPF and more important uniform UVA/UVB protection.
\end{abstract}

Key words: Sunscreen, Resveratrol, Quercetin, Curcumin, Safranal, SPF.

\section{INTRODUCTION}

From the dawn of mankind, Sun is source of life and energy. But recent studies accepts sun as main culprit of deleterious effects including acute effects (e.g., sunburn and drug-induced photo toxicity) and chronic risks of frequent sun ray exposure like sunburn, crack, melanoma and pigmentation, cancer and immune suppresion. ${ }^{1}$ Sun rays are most harmful environmental factor which affects skin, cause sun burn, skin cancers and photo ageing. Due to these harmful effects of UV radiations there is need to develop sunscreen formulation to heal, prevent sun burn, suntan, skin cancer and premature skin ageing and to increase level of Sun Protection Factor. ${ }^{2}$ The goal of sunscreen formulation is to block UVrays and increase the level of protection from the UV-rays. The key components of UV protection are flavonoids, phenolic compounds or herbal oils due to their UV rays absorption capacity in UV-A region and their antioxidant activity. ${ }^{3}$ Cell mutation, DNA damage, hormone alteration and eczema like allergic reaction are some adverse effects of the synthetic sunscreen agents. Sunscreen formulations available in market don not have properties like wound healing, anti-inflammatory, cooling and anti-ageing. Again free radical mediated skin damages cannot be cured until and unless free radical scavengers are not available in photo protective products. ${ }^{4}$

During the market survey, it is found that there are many sunscreen formulations available in markets which are used in protection of skin from UV rays. Various formulations have different sun protection activity on basis of their efficacy of UV rays absorption but maximum formulations are of high cost and incorporated synthetic molecules are with potential toxicity and even carcinogenesis. ${ }^{4}$ Hence there is need to develop and evaluate effective and safe sunscreen product which can give solution to sunburn, wounds, cracks, wrinkles, premature ageing and antioxidant ingredients to help in protection of long term damaging effects of sunrays mediated free radicals.

Curcumin, quercetin, resveratrol and safranal belong to class of poly phenolics and are potent antioxidants as well as photo protective. But additionally curcumin is wound healing, antiseptic; quercetin is anticancer, resveratrol is antiaging and safranal is emollient. ${ }^{5-10}$ So sunscreen product incorporated with these ingredients can give desired all-in-one product.

Curcumin (diferuloylmethane) is a yellow odorless pigment isolated from the rhizome of turmeric (Curcuma longa). Curcumin possesses anti-inflammatory, antitumoral, and antioxidant properties. It has been found that topical application of curcumin in epidermis of CD-1 mice significantly inhibited UVA-induced ornithine decarboxylase ornithine decarboxylase (ODC) activity. The inhibitory effects of curcumin were attributed to its ability to scavenge reactive oxygen species reactive oxygen species (ROS). Curcumin can prevent UV irradiationinduced apoptotic changes in human epidermoid carcinoma A431 cells. ${ }^{5}$

Quercetin is polyphenolic compound present in citrus species shows strong immune modulatory, antioxidant, anti-inflammatory effects and act as a. Quercetin and rutin were tested as potential topical sunscreen factors in human beings and found to provide protection in the UVA and UVB range. ${ }^{6}$

Resveratrol is chemically fat soluble stilbenes belong to polyphenolic class. It is of trans and a cis configuration. It acts as a potent antioxidant and as well anticancer and anti-inflammatory. ${ }^{7-8}$

Safranal, an organic aromatic compound present in stigmas of crocus flowers (Crocus sativus). It exhibits high antioxidant and free radical scavenging efficacy. It is also found to be anticancer..$^{9-10}$ 


\section{MATERIALS AND METHODS}

\section{Pre-formulation studies}

Quercetin, curcumin and resveratrol were purchased from THS, Mumbai. Safranal was purchased from KuberImpex Limited, Indore. Drugs were identified by various physical parameters (Table 2), spectroscopic studies ${ }^{11}$ (Figure 1 and 2) and chromatographic studies (Figure 3 and 4). ${ }^{12}$ Various confirmatory chemical tests performed to identify purchased chemicals. And thus selected phy to chemicals further processed to know SPF values and antioxidant activity.

\section{In vitro SPF determination of active phyto chemicals}

Initial stock solution was prepared by taking $1 \% \mathrm{w} / \mathrm{v}$ pure drug (curcumin, quercetin, resveratrol and safranal) in ethanol: distilled water (40:60). Then from this stock Solution, $0.1 \%$ stock solution was prepared. Thereafter, absorbance values of each aliquot prepared were determined from 290-320 nm, at $5 \mathrm{~nm}$ intervals, taking ethanol: distilled water (40: 60) solution as blank, using Shimadzu UV-Spectrophotometer. Determinations were made in triplicate at each point. SPF of active drugs for were calculated by the application of equation: ${ }^{13}$

$$
\mathrm{SPF}=\mathrm{CF} \sum_{290}^{320} \mathrm{EE}(\lambda) \times \mathrm{I}(\lambda) \times \operatorname{Abs}(\lambda)
$$

The aliquot prepared were scanned between $290-320 \mathrm{~nm}$ and the obtained absorbance values were multiplied with the respective $\mathrm{EE}(\lambda)$ and $I(\lambda)$ values. Then, their summation was taken and multiplied with the correction factor $(10)$

\section{In-vitro antioxidant activity determination by DPPH Method}

$1 \mathrm{ml}$ different concentration of active drug and standard were taken in different vials. To this $5 \mathrm{ml}$ of methanolic solution of DPPH was added, shaken well and mixture was incubated at $37^{\circ} \mathrm{C}$ for $20 \mathrm{~min}$. The absorbance was measured against methanol as blank at $516 \mathrm{~nm}$. Absorbance of DPPH was taken as control. ${ }^{14-15}$ Percentage antiradical activity calculated by using following formula;

$$
\% \text { Anti }- \text { radical activity }=\frac{\begin{array}{l}
\text { Control Absorbance }- \\
\text { Sample Absorbance }
\end{array}}{\text { Control Absorbance }} \times 100
$$

\section{Development of Formulation}

About 20 cream bases were formulated in the preliminary study. The components used were in a generally recognized as safe (GRAS) status. The cream bases were prepared via emulsification process. Briefly, an oil phase containing lipophilic substances and an aqueous phase containing hydrophilic substances were separately heated in a water bath to $80^{\circ} \mathrm{C}$. Afterwards, the aqueous phase was gradually added into the oil phase with constantly stirring until the mixture was congealed at the room temperature. ${ }^{16}$ The resulted cream bases were optically observed for appearance, texture and spread ability. It was found that three cream bases had desirable properties; however, only two bases provided good characteristics after incorporated with pure phyto chemicals. Cream formulations of varying phyto chemicals composition were developed. All studied concentrations were in the legislated range. Compositions are shown in Table 1.

\section{Evaluation of Formulation Physical Parameters}

Appearance, color and homogeneity are determined. Results are shown in the Table 12 and Figure 5.

\section{Subjective Properties}

Consistency, feel on application and irritation parameters are determined and results are shown in the Table 12.

\section{Spread ability}

Two glass slides of standard dimensions $(20 \times 5 \mathrm{~cm})$ were selected. The formulation was over one of the slide. The other slide placed on the top of the cream such a that the formulation sandwiched between the two slides in an area occupied by a distance of $7.5 \mathrm{~cm}$, alongside $100 \mathrm{gm}$ weight was placed uniformly to form a thin layer. The weight was removed and the excess of cream adhering to the slides was scrapped off. The two slides in a position were fixed to stand $\left(45^{\circ}\right.$ angle) without slightest disturbance and in such a way that only the lower slide held firmly by the opposite fangs of the clamps allowing the upper slide to slip off freely by the force of weight tied to it. $60 \mathrm{gm}$ of weight was tied to the upper slide carefully. The time taken for the upper slide to travel the distance of $5 \mathrm{~cm}$ and separate away from the lower slide under the direction of weight was noted. The experiment repeated for 3 times and the mean taken for three such dimensions was calculated. ${ }^{17}$ The results were recorded. The Spread ability is calculated by using formula: $S=M^{\star} L / T$ Where, $S=$ Spread ability, $\mathrm{L}=$ Length of glass slide, $\mathrm{M}=$ Weight tied to the upper slide and $\mathrm{T}=$ Time. In present experiment $\mathrm{M}=60 \mathrm{gm}$ and $\mathrm{L}=7.5 \mathrm{~cm}$. The data showing the Spread ability of different formulation are in the Table 12.

\section{Extrudability}

The cream formulation was filled in the standard capped collapsible aluminum tubes and sealed by crimping the ends. The weight of the tubes was recorded. The tube was placed between two glass slides and was clamped. A 500 gm cream was placed over the glass slides and then the cap was removed. The amount of cream extruded was collected and weighed. ${ }^{16}$ The percent of cream was calculated and graded as fallow:

\begin{tabular}{llcc}
$90 \%$ & \multicolumn{2}{c}{ Extrudability $=++++$ Excellent } & \\
$80 \%$ & Extrudability $=$ & \multicolumn{2}{c}{+++ Good } \\
$70 \%$ & Extrudability $=$ & ++ & Fair \\
$50 \%$ & Extrudability $=$ & + & Poor \\
\hline
\end{tabular}

The Extrudability of all the formulation is tabulated in Table 12.

\section{Thermal stability}

In this test the oil separation from the cream were tested at $60-70 \% \mathrm{RH}$ and $37 \pm 1^{\circ} \mathrm{C}$ in humidity chamber. In this a $20 \mathrm{~mm}$ broad and $5 \mathrm{~mm}$ stripe of cream were spread on the internal wall of the chamber of 100 $\mathrm{ml}$ capacity, in its total heights. The beaker kept for $8 \mathrm{hrs}$ in humidity chamber at $60-70 \% \mathrm{RH}$ and temperature $37 \pm 1^{\circ} \mathrm{C}$. To pass the test there should not be any oil separation in the cream. ${ }^{17}$ the results are shown in the Table 12 .

\section{pHDetermination}

Cream might have variety of $\mathrm{pH}$ mostly ranging from 5 to 9 . The cream in general has a pH 6 to 9 . Hazelton reported that there is little correlation between $\mathrm{pH}$ and irritancy. The electrode must be washed and free from any residue of acid and alkali to ensure the accurate reading. Procedure: All the formulations were oil in water semisolid emulsions. As $\mathrm{pH}$ of the cream not to be directly measured, here $10 \%$ dilutions were made with distilled water and the resulting $\mathrm{pH}$ of mixture was determined with a $\mathrm{pH}$ meter. ${ }^{18}$ The results are shown in the Table 12.

\section{Rancidity}

This test is performed by using the Phloroglucinol solution. The rancidity is due to the oxidation of the fats and oils; during oxidation free fatty acids are liberated. These free fatty acids react with the Phloroglucinol solution and gives pink colour. This indicates the rancidity of the product. 


\begin{tabular}{cccccc}
\hline \multicolumn{6}{l}{ Table 1: Formulae for development of trial batches of Photo protective cream formulations } \\
\hline Ingredients & F - I & F -II & F- III & F-IV & F-V \\
\hline Curcumin & 4 & - & - & - & 4 \\
Quercetin & - & 3 & - & - & 3 \\
Resveratrol & - & - & 4 & - & 4 \\
Safranal & - & - & - & 3 & 3 \\
Cetostearyl alcohol & 5 & 5 & 5 & 5 & 5 \\
Stearic acid & 2 & 2 & 2 & 2 & 2 \\
PEG-200 & 2 & 2 & 2 & 2 & 2 \\
Cetyl alcohol & 1 & 1 & 1 & 1 & 1 \\
Methyl paraben & 0.3 & 0.3 & 0.3 & 0.3 & 0.3 \\
Propyl paraben & 0.06 & 0.06 & 0.06 & 0.06 & 0.06 \\
Carbopol 940 & 0.5 & 0.5 & 0.5 & 0.5 & 0.5 \\
Disodium EDTA & q.s & q.s & q.s & q.s & q.s \\
Triethanolamine & 0.5 & 0.5 & 0.5 & 0.5 & 0.5 \\
Distilled Water q. s. to 100 gm & & & & & \\
\hline
\end{tabular}

$10 \mathrm{ml}$ of melted cream was taken then added $10 \mathrm{ml}$ of concentrated hydrochloric acid and $10 \mathrm{ml}$ of Phloroglucinol solution and shaken for one minute. The material shall be taken to have passed the test if no pink colour developed. The results are shown in the Table 12.

\section{Viscosity}

Viscosity of creams was measured by the Brookfield viscometer. The correct spindle was selected (spindle no. 4) for the given product then the operating condition was setup. Then the viscosity was measured directly at $6 \mathrm{rpm}$ speed by keeping the torque constant. ${ }^{17}$ The mean was obtained. The results are shown in the Table 12 . The viscosity is determined by following formula:

Viscosity $=$ Dial Reading $\times$ Factor. For LV-4 at 6 RPM Factor is $1 \mathrm{M}(1000)$

\section{Photo stability determination}

$2 \mathrm{mg} / \mathrm{cm} 2$ of each sunscreen cream was weighed and spread evenly between two plates of polished fused quartz silica (thickness $5 \mathrm{~mm}$ and diameter $25 \mathrm{~mm}$ ). The amount applied was. To avoid absorption distortion, thinner layer was applied. The AUC for UVA, UVA1 (340-400 nm), UVA2 (320-340 nm) and UVB was measured for each spectrum before (AUC before) and after (AUC after) UV art $(980 \mathrm{~kJ} / \mathrm{m} 2 \mathrm{UVA}$ and $12 \mathrm{~kJ} / \mathrm{m} 2$ of UV radiation (UVB included) and before and after UV nat. If the AUCI (AUCI $=$ AUC after/AUC before) was $>0.80$, the sunscreen was considered photostable. ${ }^{18}$ The AUC was calculated with the following equation:

$$
\sum_{\lambda \min }^{\lambda \max } \mathrm{A}(\lambda) \Delta \lambda
$$

where $\mathrm{A}$ is absorption and $\lambda$ is wavelength. It was measured in steps of $1 \mathrm{~nm}$.

For UVA $\lambda_{\max }=400 \mathrm{~nm}$ and $\lambda_{\text {min }}=320 \mathrm{~nm}$.

The same measurement was done for every UV range respectively, before and after UVart and before and after UV nat.

\section{In-vitro occlusion studies}

Complete coverage of the surface of the skin indicates occlusion of skin. The occlusivity of cream can be measured by occlusion factor $\mathrm{F}=100^{*}$ $\mathrm{A}-\mathrm{B} / \mathrm{A}$ where $\mathrm{A}=$ water loss without sample and $\mathrm{B}=$ water loss with sample. Filter paper covered water-filled beaker method is used here. The minimum occlusion factor is 0 which indicates no occlusion effect and maximum occlusion factor is 100 which indicate complete surface coverage by topical formulation. ${ }^{19}$

50 to 200-mg of each sunscreen cream was applied evenly on the filter paper surface to create solid film which was found about amount of $8.5 \mathrm{mg} / \mathrm{cm}^{2}$. Reference control was actually a beaker covered with filter paper without sample application. Store the samples at $32^{\circ} \mathrm{C}$ and $50-55 \%$ $\mathrm{RH}$ for 48 hours. Meanwhile the samples were weighed after 6, 24, and 48 hours to determine water flux or evaporation through the filter paper. ${ }^{19}$ Every experiment was performed in triplicate.

\section{In-vitro skin permeation studies}

In-vitro skin permeation measurements are done by a piece of the dorsal full thickness skin of Wistar rats devoid of hair and fat. $0.5 \mathrm{~g}$ of cream was applied to skin piece and mounted in Franz Diffusion cell. PBS serves as a receptor fluid. After $24 \mathrm{~h}$, the amount of drug in the receptor compartment, the drug remaining on the skin, and the drug in the skin was determined by UV-vis spectrophotometer followed by extracting skin piece in alcohol. ${ }^{19}$

\section{Total poly phenolic content determination}

The Folin-Ciocalteu reagent (FCR) or Folin's phenol reagent or FolinDenis reagent or Gallic Acid Equivalence method (GAE) uses a mixture of phosphomolyb date and phosphotungstate for the colorimetric assay of phenolic and polyphenolic antioxidants. It works by measuring the amount of the substance needed to inhibit the oxidation of the reagent. However, this reagent does not only measure total phenols but will react with any reducing substance. The reagent, therefore, measures the total reducing capacity of a sample, not just the level of phenolic compounds. This reagent forms part of the Lowry protein assay and will also react with some nitrogen-containing compounds such as hydroxylamine and guanidine.

\section{Reagents}

- Dilute Folin-Ciocalteu reagent with equal volume of distilled water,

- $20 \%$ sodium carbonate in water, and

- Gallic acid.

Prepare calibration curve of standard Gallic acid (10-100 $\mu \mathrm{g} / \mathrm{ml}$ in water). Prepare $1 \mathrm{milligram} / \mathrm{ml}$ of extract solutions. Mix $1 \mathrm{ml}$ of each sample with $0.25 \mathrm{ml}$ of FolinCiocalteu reagent and $1.25 \mathrm{ml}$ of $20 \%$ sodium 
carbonate solution. Allow the mixture to react for $40 \mathrm{~min}$. at room temperature. After the reaction period, mix the contents and measure the blue color at $725 \mathrm{~nm}$ in comparison with standards. Calculate the amount of total phenols from calibration curve as a Gallic acid equivalent by the following formula. ${ }^{20}$

$$
\mathrm{T}=\frac{\mathrm{C} \times \mathrm{V}}{\mathrm{M}}
$$

Where,

$\mathrm{T}$ is total content of phenolic compounds, (milligram per gram of plant extract),

C: the concentration of gallic acid established from the calibration curve(milligram per milliliter),

$\mathrm{V}$ : the volume of extract (milliliter) and $\mathrm{M}$ is the gram weight of plant extract.

\section{In-vitro Antioxidant Activity}

$1 \mathrm{ml}$ different concentration of active drug and standard were taken in different vials. To this $5 \mathrm{ml}$ of methanolic solution of DPPH was added, shaken well and mixture was incubated at $37^{\circ} \mathrm{C}$ for $20 \mathrm{~min}$. The absorbance was measured against methanol as blank at $516 \mathrm{~nm}$. Absorbance of DPPH was taken as control. Percentage antiradical activity calculated by using following formula. ${ }^{14,15}$ the results are shown in the Table 3.

$$
\% \text { Anti }- \text { radical activity }=\frac{\begin{array}{l}
\text { Control Absorbance }- \\
\text { Sample Absorbance }
\end{array}}{\text { Control Absorbance }} \times 100
$$

\section{Determination Sun Protection Factor (SPF)}

\section{In-vitro Determination Sun Protection Factor (SPF) by UV-spectrophotometer}

Creams: 1 gm quantity of formulated cream was weighed, transferred to $100 \mathrm{ml}$ volumetric flask and diluted to volume with ethanol. Further, it was kept for ultra-sonication for 5 min and filtered through cotton filter, discarded the initial $10 \mathrm{ml}$. Afterwards $5 \mathrm{ml}$ aliquot was transferred to $25 \mathrm{ml}$ volumetric flask and the volume was adjusted with ethanol. The absorption spectra of samples in solution were obtained in the range of 290-450 $\mathrm{nm}$ using $1 \mathrm{~cm}$ quartz cell and ethanol as blank. The absorption data obtained in the range of 290-320 nm every $5 \mathrm{~nm}$ interval and 3 determinations were made at each point. ${ }^{13}$ The absorbance values and results of formulation I, II and III are shown in Table 9.

Marketed Sunscreen Products: Two marketed formulations were selected. The results of marketed formulation I and formulation II are shown in the Table 9.

Synthetic Sunscreen Agents: The in-vitro determination SPF of synthetic sunscreen agents (Oxybenzone and Avobenzone) was done by UV-Spectrophotometer. These sunscreen agents are widely used in the sunscreen formulation. The results of oxybenzone and avobenzone are shown in the Table 9.

Sun Protection Factor Determination: SPF of formulated creams, marketed sunscreen products and synthetic sunscreen agents were calculated by the application of equation:

$$
\mathrm{SPF}=\mathrm{CF} \sum_{290}^{320} \mathrm{EE}(\lambda) \times \mathrm{I}(\lambda) \times \operatorname{Abs}(\lambda)
$$

The aliquot prepared were scanned between $290-320 \mathrm{~nm}$ and the obtained absorbance values were multiplied with the respective $\mathrm{EE}(\lambda)$ and I $(\lambda)$ values. Then, their summation was taken and multiplied with the correction factor (10)

\section{In-vitro Determination of SPF by UV 2000S Ultraviolet} Transmittance Analyzer (Labsphere)

Procedure: Approximately $110 \mathrm{mg}$ of the prepared investigational sample was applied and spread on the $56 \mathrm{~cm}^{2}$ area to obtained a sample film thickness of $2 \mu \mathrm{l} / \mathrm{cm}^{2}$ on Transpore Tape to get an even film as suggested in the operation manual of the UV-2000S Ultraviolet Transmittance Analyzer for the sample preparation and application technique. The sample thus prepared was exposed to Xenon flash Lamp for determining the Sun Protection Factor. The calculation and results are shown in the Table 9. Critical Wavelength $(\lambda c)$ associates with level of protection$340 \leq \lambda c 370 \mathrm{~nm}$ - Some (UVA/UVB), $\lambda c 370 \mathrm{~nm}$ - More (Broad Spectrum). The topical natural formulation evaluated for all cream parameters and in-vitro SPF determination. The Boots Star Rating and Critical wavelength are associated with the claim for UV-A protection, as formulation show the UVA/UVB ratio 0.825; hence, there four Boot Star Rating. Critical Wavelength was found 388.00 showing that the formulation can provide excellent UVA/UVB Protection..$^{21}$ The result of Boots Star Rating of Formulation F-V is mentioned in Table 9.

\section{Skin Irritation Study}

The experimental protocol for this study was approved by the Institutional Animal Ethics Committee (IAEC) and the care of animals was taken according to the guidelines of CPCSEA, Ministry of Forests and Environment, Government of India.

- Experimental Animals: 3 Sprague Dawley Male Rats of 8 weeks age, weighing approximately 250-300 gm to test for the skin irritation.

- Preparation of Animals prior to testing: The back skin of area $6 \mathrm{~cm}^{2}$ of each rat was shaved prior to the experiment and the animals were divided as

- Control Animal: No formulation was applied

- Test Animals (Cream formulation Animal): Formulation containing active ingredients was applied.

- Base Formulation Animal: Formulation containing only excipients (No active ingredients) cream base was applied.

No formulation was applied to group of control rats for whole period of experiment. $0.5 \mathrm{gm}$ of herbal cream formulation was used as the test substance and applied to an area of approximately $6 \mathrm{~cm}^{2}$ of skin and covered with a gauze patch. The patch was loosely held in contact with the skin by means of semi occlusive dressing for the duration of 1 hour and gauze was removed. At the end of exposure period ( 1 hour) residual test substance was removed without altering the existing response or the integrity of the epidermis. Observations were recorded after removal of the patch. $0.5 \mathrm{gm}$ of base formulation i.e. cream formulated using all ingredients except the active drug materials, was applied to the animals and observations were made as similar to the test animals. ${ }^{21}$

\section{Stability studies \\ Stability by Centrifugation}

During the centrifugation studies, sunscreens were centrifuged at 3500$13,500 \mathrm{rpm}$ at interval of $500 \mathrm{rpm}$ for $10 \mathrm{~min} .^{22}$ The formulations were observed for the phase separation. The results are shown in the Table 7

\section{Stability studies as per ICH guidelines}

For assessing the stability of formulated creams, the following parameters were taken into consideration like color, liquefaction, phase separation, viscosity; extrude ability, Spread ability, $\mathrm{pH}$ and SPF of formulation. These studies are essential to ensure that the product is stable throughout its designated shelf life. ${ }^{22}$ The stability was carried out for thirty days at temperatures $40 \pm 2^{\circ} \mathrm{C}$ and relative humidity at $75 \pm 5 \%$ using stability chamber. 
Table 2: Results of evaluation by physical parameters

\begin{tabular}{cccccc}
\hline Drug & Colour & Odour & Solubility & Melting point & UVmax wavelength $(\mathrm{nm})$ \\
\hline Curcumin & Bright yellow to orange & Characteristic & Methanol & $181-183^{\circ} \mathrm{C}$ & 420 \\
Quercetin & Pale yellow & Odorless & Alkaline solution & $314-316^{\circ} \mathrm{C}$ & 375 \\
Resveratrol & White with yellow tinge & Characteristic & Ethanol & $261-263^{\circ} \mathrm{C}$ & 310 \\
Safranal & Colorless & Aromatic & Ethanol & $68^{\circ} \mathrm{C}$ & 308 \\
\hline
\end{tabular}

\section{RESULTS AND DISCUSSION}

\section{Physical parameters}

Physical evaluation like color, odor, solubility and melting point of purchased drugs were performed to confirm identity. All phyto chemicals were separated and confirmed by TLC. Chromatographic analysis ${ }^{20}$ using silica gel $G$ as stationary phase and toluene: ethyl acetate (7:3) showed presence of curcumin at 8.2 , quercetin at 8.2 and resveratrol at 8.0 and safranal at 7.2 RF value. Results are shown in Figure 1. All phyto chemicals were identified by HPLC. Chromatographic conditions were used are as follows and graphs are from Figure 2 (a) to 2 (d).

All phyto chemicals were confirmed by UV-visible and FTIR Spectroscopic studies. ${ }^{11}$ Spectrums are shown in Figure 3 to 4 . Determination of UVmax of pure purchased phyto chemicals was done. Curcumin, quercetin, resveratrol and safranal showed 420, 375, 310 and $308 \mathrm{~nm}$ UVmax respectively. Drug excipients interaction study is very significant in relation to know compatibility of selected excipients with active drugs. Incompatibility is actually inactivation of active drug due to decomposition or alteration to a less effective physical or chemical form. When mixture of 2 or more active drugs and excipients are mixed together then chances of interaction with respect to change in appearance, elegance and most important chemistry of each other. To know chemical changes or interactions, generally chromatographic, spectroscopic and thermal analyses are preferred methods. Here TLC and FTIR studies are done for individual active drugs and final optimized formulation.

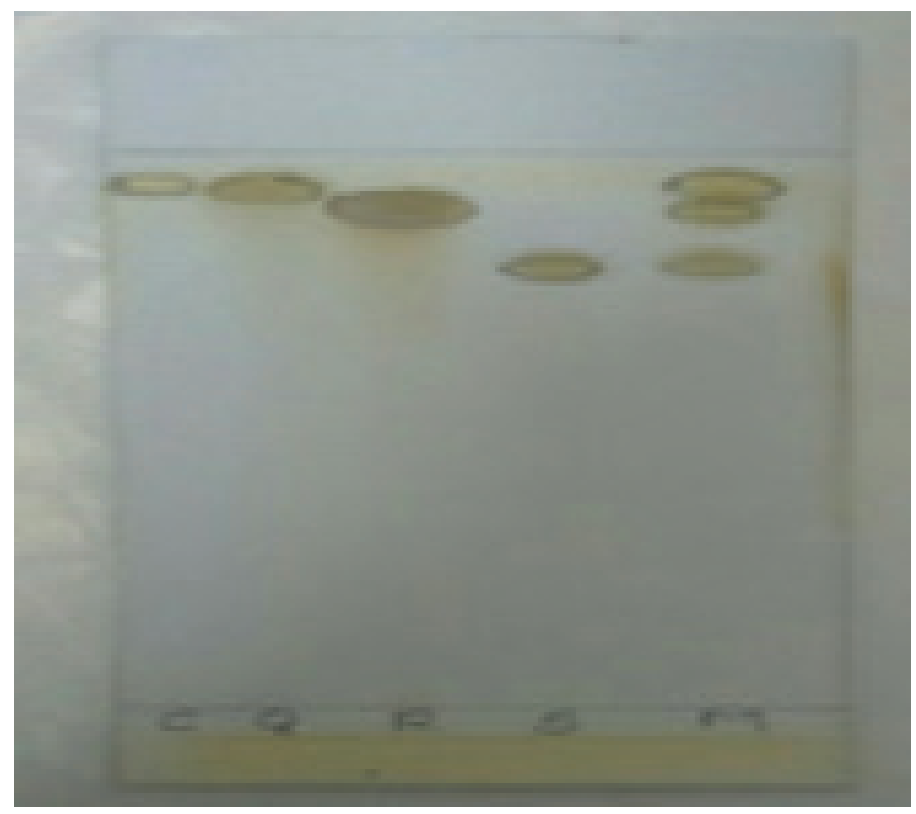

Figure 1: TLC of phytochemicals. Stationary Phase: Silica Gel F $\mathrm{F}^{254}$ Mobile phase: Toluene: Ethyl acetate (7:3), Detection: lodine chamber Where C: Curcumin, Q: Quercetin, R: Resveratrol, S: Safranal and M: Mixture of all four constituents.

\section{In-vitro SPF determination of active phytochemicals}

All preliminary parameters and spectroscopic studies complied with previous literature standards and thus selected phytochemicals further processed to know SPF values.Values for curcumin, quercetin, resveratrol and safranal are shown in Table 3. SPF of curcumin, quercetin, resveratrol and safranal were found to $11.58,14.81,21.53$ and 10 respectively measured by UV-Visible spectroscopic method. Resveratrol showed highest SPF value while safranal showed lowest SPF value.

\section{In vitro antioxidant activity of active phytochemicals}

Percentage antiradical activity calculated by DPPH method. DPPH $(1,1$ diphenyl-2-picryl-hydrazyl) is stable free radical means which after reaction with antioxidant compound do not become unstable. Methanolic solution of it is used to evaluate the antioxidant activity of several natural compounds. 82.2, 81.04, 63.46, 72.14 and $51.15 \%$ antioxidant activity exhibited by standard ascorbic acid, curcumin, quercetin, resveratrol and safranal respectively as shown in Table 4 . All four selected polyphenolic phyto chemicals showed significant antiradical percentage at very low concentration and thus decided to be incorporated in formulation development.

\section{Development of Formulation}

As compared to lotion or any other dosage form, creams are more efficient due to good stability, spread ability, occlusivity, penetration power and cost effectiveness. Long contact time and hydrophobic active drug solubility in oil phase keeps cream dosage forms always a choice of manufacturers. Cream formulations of varying phyto chemicals composition were developed. All studied concentrations were in the legislated range. ${ }^{5-}$ ${ }^{10}$ Compositions are shown in Table 1.

Step I: Aqueous Phase Preparation: Disodium EDTA, Sodium Methyl Paraben and Triethanolamine weighed accurately and dissolved in De ionized Water; meanwhile, Carbopol was added to swell using a homogenizer and heated up to $80^{\circ} \mathrm{C}$.

Step II: Oil Phase Preparation: Sodium propyl paraben, Stearic acid, Cetyl alcohol, Polyethylene glycol, Cetostearyl alcohol and respective quantities of essential active drugs curcumin, quercetin ,rutin and quercetin derivatives weighed accurately and mixed and heated at $80^{\circ} \mathrm{C}$.

Step III: Mixing Phase: Oil phase was added to aqueous phase at $80^{\circ} \mathrm{C}$ with continuous stirring for $20-25 \mathrm{~min}$ and then it was homogenized till uniform emulsion formed. It was then poured into the wide mouth container and stored at temperature not exceeding $37^{\circ} \mathrm{C}$.

\section{Pharmaceutical Evaluation of Formulation}

\section{Physical Parameters}

Appearance, color and homogeneity are determined. Results are shown in the Table 12. All formulations found to be uniform and homogenous (Figure 5).

\section{Subjective Properties}

Consistency, feel on application and irritation parameters are determined and results are shown in the Table 12. A result shows that all 


\begin{tabular}{|c|c|c|}
\hline Parameters & Curcumin & \\
\hline Flow rate & $0.80 \mathrm{ml} / \mathrm{min}$ & \\
\hline Stationary phase/column & $\mathrm{C}_{18}$ & \\
\hline Mobile Phase & $\begin{array}{l}\text { Acetonitrile : water : } 100 \mathrm{mM} \text { formic } \\
\text { acid }(70: 10: 20)\end{array}$ & \\
\hline Methods & Isocratic & \\
\hline Detection & $\begin{array}{l}\text { Photodiode array detector } \\
200-500 \mathrm{~nm}\end{array}$ & 1 \\
\hline Retention time & $\begin{array}{c}1.1 \\
\text { Quercetin }\end{array}$ & Figure 2 (a): HPLC chromatograph of Curcumin. \\
\hline Flow rate & $1 \mathrm{ml} / \mathrm{min}$ & \\
\hline Stationary phase/column & $\mathrm{C}_{18}$ & \\
\hline Mobile Phase & $\begin{array}{l}\text { Methanol: } 0.1 \% \text { ortho phosphoric acid } \\
\qquad(65: 35)\end{array}$ & \\
\hline Methods & Isocratic & \\
\hline Detection & $369 \mathrm{~nm}$ & \\
\hline \multirow[t]{3}{*}{ Retention time } & 8.4 & \\
\hline & & Figure 2 (b) : HPLC chromatograph of Quercetin. \\
\hline & Resveratrol & \\
\hline Flow rate & $1 \mathrm{ml} / \mathrm{min}$ & 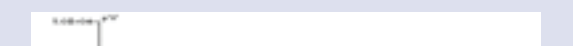 \\
\hline Stationary phase/column & $\mathrm{C}_{18}$ & $\cdots$ \\
\hline Mobile Phase & $\begin{array}{l}\text { methanol: } 10 \mathrm{mM} \text { potassium dihydrogen phosphate buffer }(\mathrm{pH} 6.8) \text { : } \\
\text { acetonitrile }(63: 30: 7, \mathrm{v} / \mathrm{v} / \mathrm{v})\end{array}$ & $\ldots$ \\
\hline Methods & Isocratic & $\ldots$ \\
\hline Detection & $306 \mathrm{~nm}$ & $\begin{array}{rl}2 & 1 \\
\end{array}$ \\
\hline \multirow[t]{2}{*}{ Retention time } & 3.2 & Figure 2 (c): HPLC chromatograph of Resveratrol. \\
\hline & Safranal & \\
\hline Flow rate & $1 \mathrm{ml} / \mathrm{min}$ & $\cdots+\cdots$ \\
\hline Stationary phase/column & $\mathrm{C}_{18}$ & ...... \\
\hline Mobile Phase & Acetonitrile & $\ldots$ \\
\hline Methods & Isocratic & $\ldots+\ldots$ \\
\hline Detection & Photodiode array detector & $=$ \\
\hline & $200-350 \mathrm{~nm}$ & \\
\hline \multirow[t]{2}{*}{ Retention time } & 3.8 & 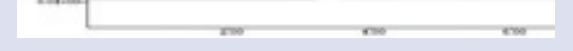 \\
\hline & & Figure 2 (d): HPLC chromatograph of Safranal. \\
\hline
\end{tabular}

formulations have good subjective properties such as consistency, texture and irritation on skin when it applied on the skin.

\section{Spread ability}

The spread ability of formulated cream was determined which indicates good spreading of cream when applied to the skin. Results are summarized in Table 12.

\section{Extrude ability}

This test is the measure of the force required to extrude the material from a collapsible tube when the certain amount of force has been applied on it in the form of weight. In the present study the quantity in percentage of cream extruded from the tube on application of certain load. ${ }^{17}$ Results show that the all formulations have good extrude ability. The good extrude ability and Spread ability are required for the therapeutic efficiency of the formulation.

\section{Thermal stability}

In this test the oil separation from the cream were tested at $60-70 \% \mathrm{RH}$ and $37 \pm 1^{\circ} \mathrm{C}$ in humidity chamber. All these five formulations when placed in humidity chamber at $60-70 \% \mathrm{RH}$ and $37 \pm 1^{\circ} \mathrm{C}$ temperature there is no phase separation. This shows that formulations are thermally stable.

\section{pH Determination}

The $\mathrm{pH}$ of creams was determined to examine the possible side effects due to acidic or alkaline $\mathrm{pH}$, which can leads to irritation of skin. Acidic or alkaline $\mathrm{pH}$ may cause irritation to the skin and influence the rate of hydration of polymer. The cream in general has a $\mathrm{pH}$ 6-9. Here all these five formulation have $\mathrm{pH}$ within these range to match skin $\mathrm{pH}$ (Table 12). 


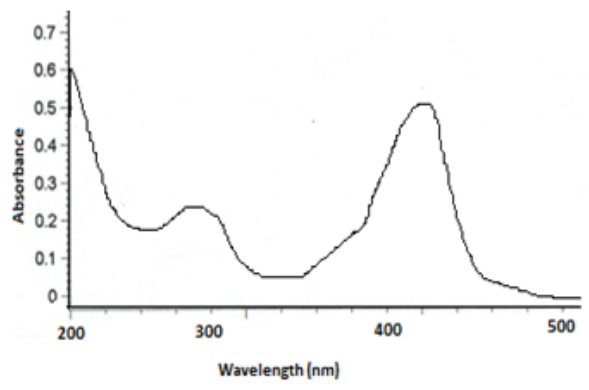

(a) Curcumin $(420 \mathrm{~nm})$ in methanol

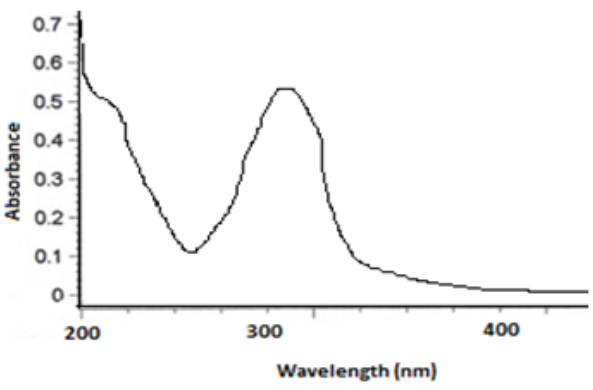

(c) Resveratrol $(310 \mathrm{~nm})$ in ethanol

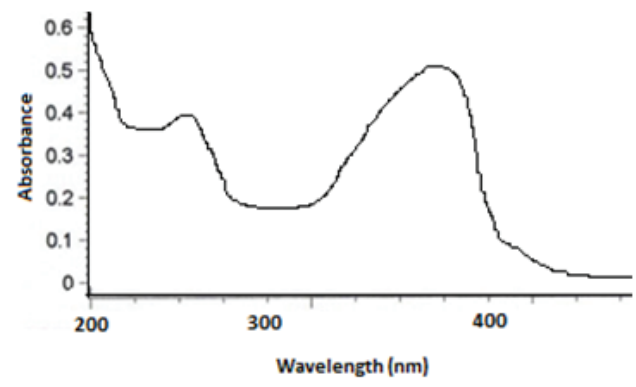

(b) Quercetin $(375 \mathrm{~nm})$ in ethanol

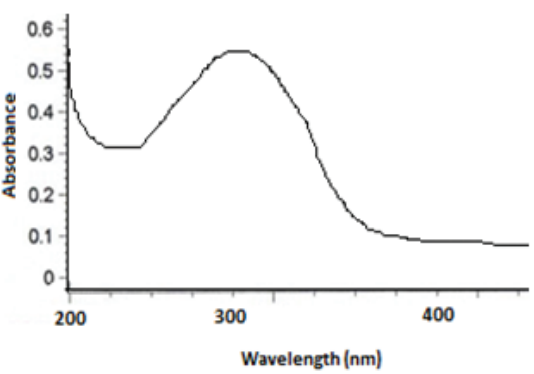

(d) Safranal $(308 \mathrm{~nm})$ in ethanol

Figure 3: UV spectrum of phytochemicals.

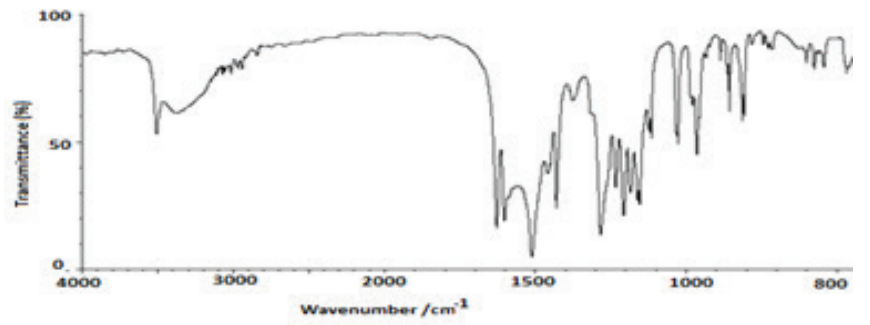

(a) FTIR spectrum of Curcumin

\begin{tabular}{cc}
\hline Wave number $\left(\mathrm{cm}^{-1}\right)$ & Details \\
\hline $3608 \mathrm{~cm}^{-1}$ & $\begin{array}{c}\text { Streching vibrations of the free } \\
\text { hydroxyl-group of phenol (Ar-OH) }\end{array}$ \\
$2992,2954 \mathrm{~cm}^{-1}$ & $\begin{array}{c}\text { C-H Streching } \\
1745 \mathrm{~cm}^{-1}\end{array}$ \\
$1568 \mathrm{~cm}^{-1}$ & $\begin{array}{c}\text { vibration of the carbonyl bond (C=O) } \\
\mathrm{C}=\mathrm{C} \text { symetric aromatic ring streching } \\
\text { corresponding to the vibrational } \\
\text { mode of C-O elongation of the } \\
\text { alcohol and phenol groups } \\
\text { Bending vibrations of the } \mathrm{C}-\mathrm{H} \text { bond } \\
\left.\text { of alkene groups ( } \mathrm{RCH}=\mathrm{CH}_{2}\right) .\end{array}$ \\
71963 and $1378 \mathrm{~cm}^{-1}$ &
\end{tabular}

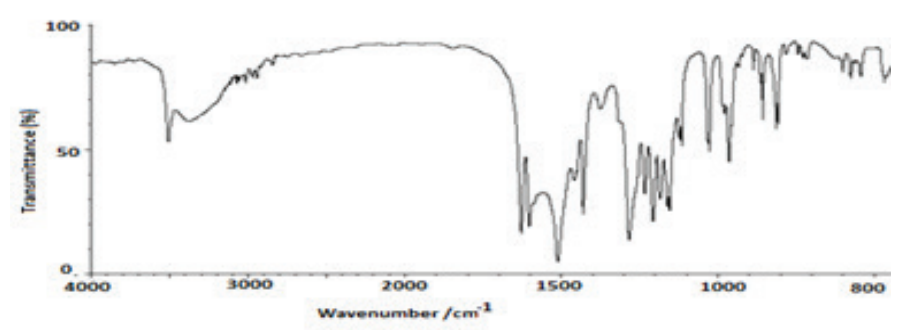

(b) FTIR spectrum of Resveratrol

\begin{tabular}{cc}
\hline Wave number $\left(\mathrm{cm}^{-1}\right)$ & Details \\
\hline $3300 \mathrm{~cm}^{-1}$ & Broad OH peak \\
3100 and $2900 \mathrm{~cm}^{-1}$ & Aromatic and aliphatic C-H bonds \\
$1750 \mathrm{~cm}^{-1}$ & An ester Peak \\
$1600 \mathrm{~cm}^{-1}$ & C=C bond \\
$1200 \mathrm{~cm}^{-1}$ & Ester C-O-C peak \\
\hline
\end{tabular}

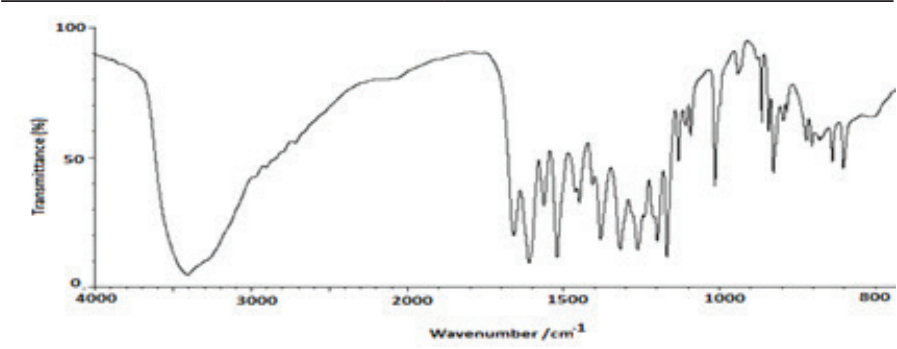

(c) FTIR spectrum of Safaranal

\begin{tabular}{cc}
\hline Wave number $\left(\mathrm{cm}^{-1}\right)$ & Details \\
\hline $3302 \mathrm{~cm}^{-1}$ & Broad OH peak \\
$2925 \mathrm{~cm}^{-1}$ & $\mathrm{C}$-H Streching \\
$2034 \mathrm{~cm}^{-1}$ & $-\mathrm{CO}$ streching \\
1699 and $1637 \mathrm{~cm}^{-1}$ & $-\mathrm{C}=\mathrm{C}$ streching \\
$1462 \mathrm{~cm}^{-1}$ & $\begin{array}{c}\text { corresponding to the vibrational } \\
\text { mode of C-O elongation of the } \\
\end{array}$ \\
$1250 \mathrm{~cm}^{-1}$ & $-\mathrm{CH}$ wagging \\
$1068 \mathrm{~cm}^{-1}$ & $-\mathrm{CH}$ streching \\
\hline
\end{tabular}




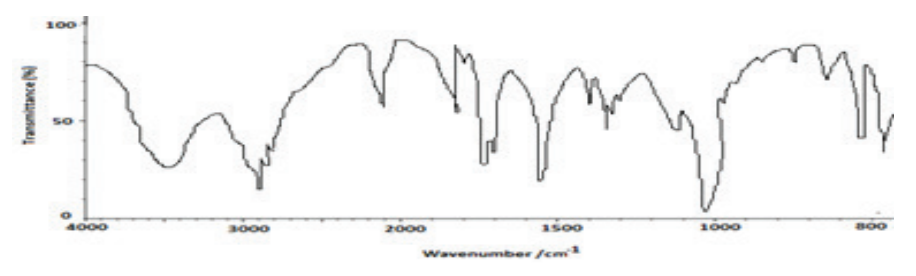

(d) FTIR spectrum of Quercetin

\begin{tabular}{cc}
\hline & Wave number $\left(\mathrm{cm}^{-1}\right)$ \\
$1663 \mathrm{~cm}^{-1}$ & O-H strech vibration of phenol \\
$1608 \mathrm{~cm}^{-1}$ & $\mathrm{C}=\mathrm{O}$ aryl KetonicStrech \\
$1383 \mathrm{~cm}^{-1}$ & C-C aromatic ring strech \\
$1318 \mathrm{~cm}^{-1}$ & O-H bending of phenol \\
$1265 \mathrm{~cm}^{-1}$ & C-H bond in aromatic hydrocarbon \\
$1203 \mathrm{~cm}^{-1}$ & C-O strech of aryl ether \\
1167 & C-O strech of phenol \\
$940,821,677$ and 602 & C-CO-C streching and bending in \\
& ketone \\
& C-H bending of aromatic \\
& hydrocarbon
\end{tabular}

Figure 4: FTIR studies of phytochemicals.

\section{Rancidity determination}

This test is performed by using the Phloroglucinol solution. The rancidity is due to the oxidation of the fats and oils; during oxidation free fatty acids are liberated. These free fatty acids react with the Phloroglucinol solution and gives pink color. This indicates the rancidity of the product. All these five-formulation show no pink color (Table 12) when shaken with Phloroglucinol and $\mathrm{HCl}$ solution, so these five formulations shows no rancidity, all oils of formulation were free from oxidation.

\section{Viscosity determination}

Viscosity is the most important parameter in the evaluation of the cream. Viscosity governs the many properties of the product such as spread ability, pour ability of the product from the container etc. The viscosity of formulations was determined using Brookfield Viscometer and Viscosity was found to be in range of $28000-32000 \mathrm{cp}$. (Table 12) The viscosity is determined by following formula:

Viscosity $=$ Dial Reading $\times$ Factor. For LV-4 at 6 RPM Factor is $1 \mathrm{M}(1000)$

\section{Photo stability determination}

The photo stability of the trial batches of sunscreen showed considerable stability of ingredients. Samples on plate showed similar spectrum before and after heating for $20 \mathrm{~min}$ at $50^{\circ} \mathrm{C}$. No change in viscosity of cream observed in before and after scanning. (Table 5) The photo unstable sunscreens begin to degrade relatively rapidly when exposed to the sun. ${ }^{18}$ After 120 min of UV nat, AUCI found to be $<0.80$ for sunscreens I to IV which indicates that these are unstable. Formulated sunscreens creams are containing organic chemical which are potent antioxidant and hence can be more. Sunscreen creams F-I, F-II, F-III and F-IV are found less photo stable than F-V after UV nat. AUCI was found between 0.66 and 0.73 for UVA and between 0.63 and 0.88 in the UVB range after $120 \mathrm{~min}$. While exposure F-V showed, shift in wavelength to shorter range and found stable by both UV art and UV nat. Thus it can be said that F-V can give consumer satisfaction for photo-stable sunscreen product. All creams showed relatively good photo stability and hence it can be considered that antioxidant nature i.e. free radical scavenging efficacy can be reason behind it. Collective antioxidant capacity of all active phyto chemicals in $\mathrm{F}-\mathrm{V}$ formulation is showing promising improved stability as compared to other batches. For the consumer it is very difficult to know what product to choose, since the photo stability varies between different brands and the photo stability is not marked on the bottle. To know which photoactive compound the sunscreen contains is not good enough. The stability also depends on factors like preservatives, oxygen radical scavengers, and base formulation.

\section{In vitro occlusion studies}

Occlusion factor of trial batches of sunscreen creams and reference control without cream were determined by in-vitro filter paper covered water-filled beaker method. The occlusive factor of all F-I to F-V was found to be greater than 85 and found to be directly depends on size of sample application. (Table 12) Occlusion is significant to moisturize and improve partitioning of skin which directly depends on thickness of applied sample layer. ${ }^{19}$

\section{In-vitro skin permeation studies}

The results of skin permeation studies are summarized in Table 12. The cumulative amount of each active drug from F-I to F-V is found between 75 to $82 \%$ which indicates a good penetration of formulated cream. Dif-

Table 3: SPF Determination of SPF of pure phytochemicals

\begin{tabular}{|c|c|c|c|c|c|c|c|c|c|}
\hline \multirow[b]{2}{*}{$\begin{array}{c}\text { Wavelength } \\
(\mathrm{nm})\end{array}$} & \multirow[b]{2}{*}{$\begin{array}{c}\text { EE }(\lambda) \times \\
I(\lambda)\end{array}$} & \multicolumn{2}{|c|}{ Curcumin } & \multicolumn{2}{|c|}{ Quercetin } & \multicolumn{2}{|c|}{ Resveratrol } & \multicolumn{2}{|c|}{ Safranal } \\
\hline & & 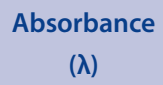 & $\begin{array}{c}\text { EE }(\lambda) \times I \\
(\lambda) \times \operatorname{Abs}(\lambda)\end{array}$ & $\begin{array}{c}\text { Absorbance } \\
(\lambda)\end{array}$ & $\begin{array}{c}\mathrm{EE}(\lambda) \times I(\lambda) \times \\
\operatorname{Abs}(\lambda)\end{array}$ & $\begin{array}{c}\text { Absorbance } \\
(\lambda)\end{array}$ & $\begin{array}{c}E E(\lambda) \times I(\lambda) \times \\
\text { Abs }(\lambda)\end{array}$ & $\begin{array}{c}\text { Absorbance } \\
(\lambda)\end{array}$ & $\begin{array}{c}\mathrm{EE}(\lambda) \times I(\lambda) \\
\times \operatorname{Abs}(\lambda)\end{array}$ \\
\hline 290 & 0.015 & 1.124 & 0.01686 & 2.422 & 0.03633 & 1.452 & 0.02178 & 1.389 & 0.02084 \\
\hline 295 & 0.0817 & 1.273 & 0.104 & 3.6121 & 0.29511 & 1.633 & 0.13342 & 1.472 & 0.12026 \\
\hline 300 & 0.2874 & 1.363 & 0.39173 & 0.9423 & 0.27082 & 1.921 & 0.5521 & 0.962 & 0.27648 \\
\hline 305 & 0.3278 & 1.182 & 0.38746 & 1.0421 & 0.3416 & 2.285 & 0.74902 & 0.774 & 0.25372 \\
\hline 310 & 0.1864 & 0.885 & 0.16496 & 1.7546 & 0.32706 & 2.381 & 0.44382 & 1.295 & 0.24139 \\
\hline 315 & 0.0837 & 0.915 & 0.07659 & 1.8416 & 0.15414 & 2.469 & 0.20666 & 0.849 & 0.07123 \\
\hline \multirow[t]{3}{*}{320} & 0.018 & 0.934 & 0.01681 & 3.144 & 0.05659 & 2.576 & 0.04637 & 0.942 & 0.01696 \\
\hline & Total $=1$ & & $\begin{array}{l}\text { Total }= \\
1.1584\end{array}$ & & Total $=1.4817$ & & Total $=2.1532$ & & $\begin{array}{c}\text { Total }= \\
1.001\end{array}$ \\
\hline & & & $S P F=11.58$ & & $S P F=14.81$ & & $S P F=21.53$ & & $S P F=10$ \\
\hline
\end{tabular}


Table 4: Antioxidant Activity determination by DPPH method

\begin{tabular}{|c|c|c|c|}
\hline Concentration & Absorbance & $\begin{array}{c}\text { Control } \\
\text { Absorbance }\end{array}$ & $\begin{array}{c}\% \text { Antioxidant } \\
\text { Activity }\end{array}$ \\
\hline \multicolumn{4}{|l|}{ Ascorbic acid } \\
\hline $100 \mu \mathrm{g} / \mathrm{ml}$ & 1.127 & 1.82 & 38.08 \\
\hline $250 \mu \mathrm{g} / \mathrm{ml}$ & 0.633 & 1.82 & 65.22 \\
\hline $500 \mu \mathrm{g} / \mathrm{ml}$ & 0.324 & 1.82 & 82.2 \\
\hline $1000 \mu \mathrm{g} / \mathrm{ml}$ & 0.105 & 1.82 & 94.23 \\
\hline \multicolumn{4}{|l|}{ Curcumin } \\
\hline $100 \mu \mathrm{g} / \mathrm{ml}$ & 1.254 & 1.82 & 31.1 \\
\hline $250 \mu \mathrm{g} / \mathrm{ml}$ & 0.895 & 1.82 & 50.82 \\
\hline $500 \mu \mathrm{g} / \mathrm{ml}$ & 0.345 & 1.82 & 81.04 \\
\hline $1000 \mu \mathrm{g} / \mathrm{ml}$ & 0.278 & 1.82 & 84.73 \\
\hline \multicolumn{4}{|l|}{ Quercetin } \\
\hline $100 \mu \mathrm{g} / \mathrm{ml}$ & 1.0915 & 1.82 & 40.03 \\
\hline $250 \mu \mathrm{g} / \mathrm{ml}$ & 0.8295 & 1.82 & 54.42 \\
\hline $500 \mu \mathrm{g} / \mathrm{ml}$ & 0.665 & 1.82 & 63.46 \\
\hline $1000 \mu \mathrm{g} / \mathrm{ml}$ & 0.395 & 1.82 & 78.3 \\
\hline \multicolumn{4}{|l|}{ Resveratrol } \\
\hline $100 \mu \mathrm{g} / \mathrm{ml}$ & 1.072 & 1.82 & 41.1 \\
\hline $250 \mu \mathrm{g} / \mathrm{ml}$ & 0.745 & 1.82 & 59.07 \\
\hline $500 \mu \mathrm{g} / \mathrm{ml}$ & 0.507 & 1.82 & 72.14 \\
\hline $1000 \mu \mathrm{g} / \mathrm{ml}$ & 0.221 & 1.82 & 87.86 \\
\hline \multicolumn{4}{|l|}{ Safranal } \\
\hline $100 \mu \mathrm{g} / \mathrm{ml}$ & 1.407 & 1.82 & 22.69 \\
\hline $250 \mu \mathrm{g} / \mathrm{ml}$ & 1.022 & 1.82 & 43.85 \\
\hline $500 \mu \mathrm{g} / \mathrm{ml}$ & 0.889 & 1.82 & 51.15 \\
\hline $1000 \mu \mathrm{g} / \mathrm{ml}$ & 0.424 & 1.82 & 76.7 \\
\hline
\end{tabular}

ferent ingredients in cream base together are generally responsible for significant permeation. ${ }^{20}$ And hence from results of in-vitro skin permeation studies it is confirmed that F-V due to efficacy of collective phyto chemicals role shows highest permeation across the skin.

\section{In-vitro Antioxidant Activity}

Endogenous production of radicals from cellular metabolism and exogenous sources from ultraviolet radiation and pollution can damage the skin on the cellular and tissue levels. Although the body possesses an elegant defense system to prevent radical damage, this innate system can be overwhelmed and lead to a state of oxidative stress or immune suppression, and can even trigger carcinogenesis. Topical supplementation of antioxidants can provide additional protection to neutralize reactive oxygen species from both endogenous and exogenous sources. 1, 1-diphenyl-2-picrylhydrazyl ( $\alpha, \alpha$-diphenyl- $\beta$-picrylhydrazyl; DPPH) is stable free radical which able to delocalise free radical to generate violet color change in ethanaol. But after reacting with antioxidant molecules, reduction takes place and loss of violet color intensity can be measured at $517 \mathrm{~nm}$. Percent inhibition of DPPH radical $=$ absorbance before reaction- absorbance after reaction/ absorbance before reaction ${ }^{\star} 100$. Mix $0.2 \mathrm{ml}$ of methanolic extract in $2 \mathrm{ml}$ of 0.5 milimolar solution of DPPH. Measure absorbance of samples and standards at $517 \mathrm{~nm}$ after $30 \mathrm{~min}$. the anti-radical activity was evaluated by DPPH method for equally diluted samples and activity found in concentration dependant manner. 75.87, 70.90, 77.45, 69.33, 50.63 and $89.83 \%$ antioxidant activity shown by ascorbic acid, FI, FII, FIII, FIV and FV respectively. (Table 6) But as compare to antioxidant activity of standard ascorbic acid, resveratrol containing formulation possesses highest antioxidant activity while safranal incorporated formulation shows lowest activity. Combined polyphenolic phyto chemicals incorporation in formulation F-V shows synergistic antioxidant activity. As the optimized cream F-V shows excellent antioxidant activity thus it can be efficient as photo protective.

Table 5: Results of photo stability evaluation of sunscreen cream batches

\begin{tabular}{|c|c|c|c|c|c|c|}
\hline \multirow[b]{3}{*}{ Formulation batches } & \multicolumn{6}{|c|}{ AUCI (AUCafter/AUCbefore) } \\
\hline & \multicolumn{2}{|c|}{$U_{\text {natural }}$} & \multicolumn{2}{|c|}{ After UV ${ }_{\text {natural }}$ exposure } & \multicolumn{2}{|c|}{ After UV $V_{\text {artificial }}$ exposure } \\
\hline & Exposure time (min) & UVA radiation $\left(\mathrm{kJ} / \mathrm{m}^{2}\right)$ & UVA & UVB & UVA & UVB \\
\hline \multirow[t]{3}{*}{ F-1 } & 30 & 55 & 0.65 & 0.68 & 0.72 & 0.72 \\
\hline & 90 & 165 & 0.68 & 0.635 & 0.65 & 0.69 \\
\hline & 120 & 235 & 0.59 & 0.61 & 0.71 & 0.77 \\
\hline \multirow[t]{3}{*}{$\mathrm{F}-2$} & 30 & 58 & 0.45 & 0.59 & 0.65 & 0.73 \\
\hline & 90 & 160 & 0.85 & 0.88 & 0.78 & 0.81 \\
\hline & 120 & 230 & 0.72 & 0.79 & 0.82 & 0.87 \\
\hline \multirow[t]{3}{*}{ F-3 } & 30 & 60 & 0.75 & 0.73 & 0.72 & 0.81 \\
\hline & 90 & 159 & 0.65 & 0.67 & 0.54 & 0.77 \\
\hline & 120 & 274 & 0.75 & 0.72 & 0.69 & 0.65 \\
\hline \multirow{2}{*}{ F-4 } & 90 & 170 & 0.64 & 0.76 & 0.66 & 0.81 \\
\hline & 120 & 284 & 0.60 & 0.70 & 0.74 & 0.77 \\
\hline \multirow[t]{3}{*}{ F-5 } & 30 & 62 & 0.75 & 0.70 & 0.60 & 0.81 \\
\hline & 90 & 155 & 0.79 & 0.72 & 0.65 & 0.80 \\
\hline & 120 & 242 & 0.84 & 0.87 & 0.90 & 0.82 \\
\hline \multirow{3}{*}{$\begin{array}{l}\text { Marketed avobenzene } \\
\text { containing formulation }\end{array}$} & 30 & 62 & 0.72 & 0.74 & 0.77 & 0.70 \\
\hline & 90 & 155 & 0.76 & 0.78 & 0.72 & 0.79 \\
\hline & 120 & 242 & 0.78 & 0.77 & 0.73 & 0.75 \\
\hline
\end{tabular}




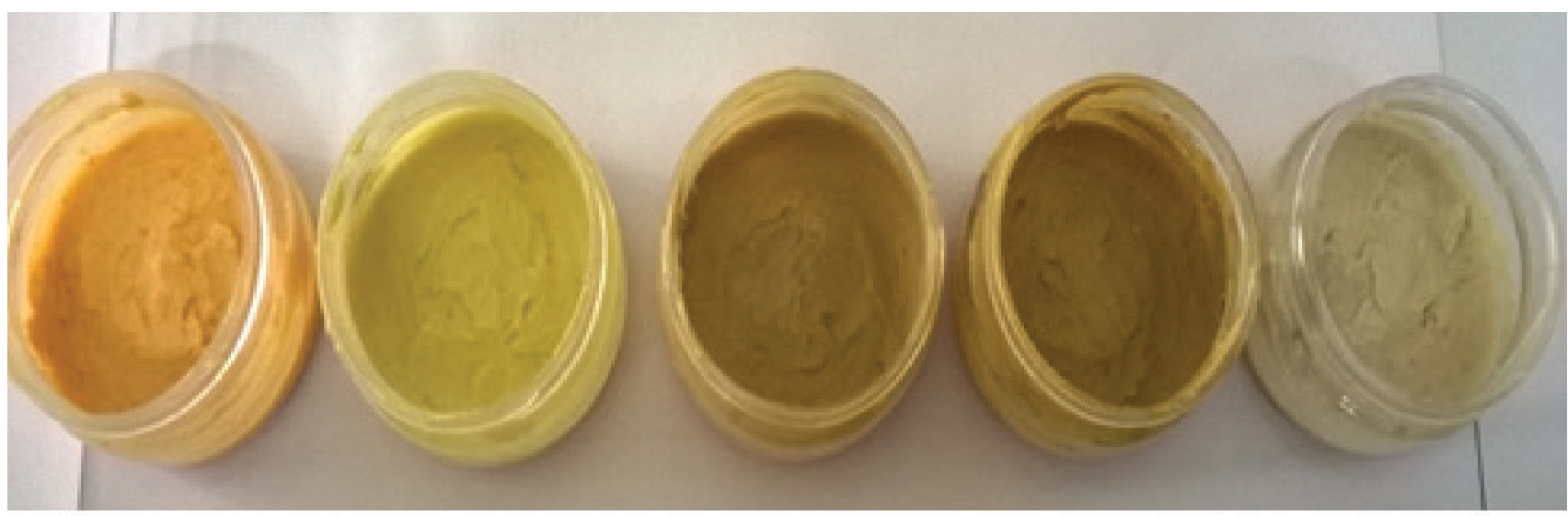

F-I F-II F-III F-IV F-V

Figure 5: Photo protective cream formulations.

\section{Table 6: Results of in-vitro antioxidant activity determination of trial batches of cream FI-to F-V}

\begin{tabular}{|c|c|c|c|}
\hline Concentration & Absorbance & Control Absorbance & $\begin{array}{c}\% \text { Antioxidant } \\
\text { Activity }\end{array}$ \\
\hline \multicolumn{4}{|l|}{ Ascorbic acid } \\
\hline $100 \mu \mathrm{g} / \mathrm{ml}$ & 1.815 & 1.712 & 65.184 \\
\hline $250 \mu \mathrm{g} / \mathrm{ml}$ & 1.711 & 1.712 & 71.258 \\
\hline $500 \mu \mathrm{g} / \mathrm{ml}$ & 1.632 & 1.712 & 75.873 \\
\hline $\begin{array}{c}1000 \mu \mathrm{g} / \mathrm{ml} \\
\text { F-I }\end{array}$ & 1.558 & 1.712 & 80.195 \\
\hline $100 \mu \mathrm{g} / \mathrm{ml}$ & 1.804 & 1.712 & 65.826 \\
\hline $250 \mu \mathrm{g} / \mathrm{ml}$ & 1.734 & 1.712 & 69.915 \\
\hline $500 \mu \mathrm{g} / \mathrm{ml}$ & 1.717 & 1.712 & 70.908 \\
\hline $\begin{array}{c}1000 \mu \mathrm{g} / \mathrm{ml} \\
\text { F-II }\end{array}$ & 1.642 & 1.712 & 75.289 \\
\hline $100 \mu \mathrm{g} / \mathrm{ml}$ & 1.937 & 1.712 & 58.057 \\
\hline $250 \mu \mathrm{g} / \mathrm{ml}$ & 1.753 & 1.712 & 68.805 \\
\hline $500 \mu \mathrm{g} / \mathrm{ml}$ & 1.605 & 1.712 & 77.45 \\
\hline $\begin{array}{c}1000 \mu \mathrm{g} / \mathrm{ml} \\
\text { F-III }\end{array}$ & 1.575 & 1.712 & 79.202 \\
\hline $100 \mu \mathrm{g} / \mathrm{ml}$ & 2.253 & 1.712 & 39.6 \\
\hline $250 \mu \mathrm{g} / \mathrm{ml}$ & 1.945 & 1.712 & 57.59 \\
\hline $500 \mu \mathrm{g} / \mathrm{ml}$ & 1.744 & 1.712 & 69.331 \\
\hline $\begin{array}{c}1000 \mu \mathrm{g} / \mathrm{ml} \\
\text { F-IV }\end{array}$ & 1.789 & 1.712 & 66.702 \\
\hline $100 \mu \mathrm{g} / \mathrm{ml}$ & 2.255 & 1.712 & 39.483 \\
\hline $250 \mu \mathrm{g} / \mathrm{ml}$ & 2.184 & 1.712 & 43.63 \\
\hline $500 \mu \mathrm{g} / \mathrm{ml}$ & 2.064 & 1.712 & 50.639 \\
\hline $\begin{array}{c}1000 \mu \mathrm{g} / \mathrm{ml} \\
\text { F-V }\end{array}$ & 1.939 & 1.712 & 57.941 \\
\hline $100 \mu \mathrm{g} / \mathrm{ml}$ & 1.712 & 1.712 & 71.2 \\
\hline $250 \mu \mathrm{g} / \mathrm{ml}$ & 1.587 & 1.712 & 78.501 \\
\hline $500 \mu \mathrm{g} / \mathrm{ml}$ & 1.393 & 1.712 & 89.833 \\
\hline $1000 \mu \mathrm{g} / \mathrm{ml}$ & 1.815 & 1.712 & 93.805 \\
\hline
\end{tabular}

\section{Stability studies}

During centrifugation studies, all five formulations were centrifuged at $3500-13,500 \mathrm{rpm}$ at interval of 10 minutes and it was observed that there was no phase separation, confirming that there was no effect of accelerated speed on formulation. Therefore, these formulations are stable. Stability studies are essential to ensure that the product is stable throughout its designated shelf life. The stability was carried out for thirty days at temperatures $40 \pm 2{ }^{\circ} \mathrm{C}$ and relative humidity at $75 \pm 5 \%$ using stability chamber. Results are shown in Table 7. All formulations had increasing viscosity values after storage in freeze-thaw condition. All samples were oil-in-water creams; hence, their water content might lose at fluctuated temperatures. Therefore, the suggested storage condition for these products should be at constant temperature. Furthermore, it was obviously found that the viscosity values of the sunscreen creams were directly related to the obtained SPF values. The formulations with suitable viscosity could provide more adhesiveness and spreading efficacy. No phase separation and changing in color as well as odor were observed in all samples after stability test; however, they seemed to be more viscous. (Figure 6 and 7) From the results it is observed the given formulations are relatively stable at accelerated temperature and humidity.

\section{Skin Irritation Study}

By stepwise order skin irritation treating should be performed which is: a weight of evidence analysis, $\mathrm{pH}$ considerations, use of validated and accepted in vitro tests, and finally refinement of the animal testing. The experimental protocol was approved by the Institutional Animal Ethics Committee (IAEC) and the care of animals was taken according to the guidelines of CPCSEA, Ministry of Forests and Environment, Govern-
Figure 6: Freshly prepared F-V formulation.

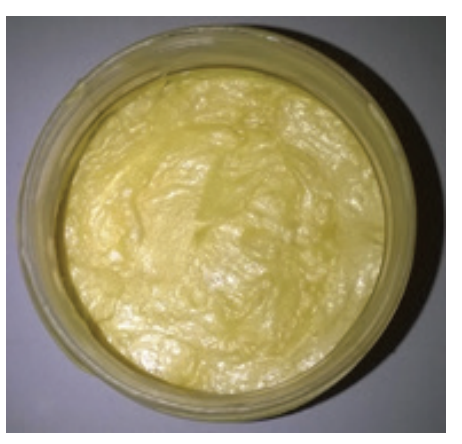

Figure 7: Formulation F-V after 3 months storage. 
Table 7: Results of Stability Study of Photo-protective Formulation

\begin{tabular}{|c|c|c|c|}
\hline Formulation & Temperature & At $40 \pm 2^{\circ} \mathrm{C} ; \mathrm{RH} 70 \pm 5$ & Stored in freeze \\
\hline \multicolumn{4}{|l|}{ Color } \\
\hline I & No change in Colour & Slight Change in colour & No change in Colour \\
\hline II & No change in Colour & Slight Change in colour & No change in Colour \\
\hline III & No change in Colour & Slight change in colour & No change in Colour \\
\hline IV & No change in Colour & Slight Change in colour & No change in Colour \\
\hline V & No change in Colour & Slight Change in colour & No change in Colour \\
\hline \multicolumn{4}{|l|}{ Phase separation } \\
\hline I & No Phase Separation & No Phase Separation & No Phase Separation \\
\hline II & No Phase Separation & No Phase Separation & No Phase Separation \\
\hline III & No Phase Separation & No Phase Separation & No Phase Separation \\
\hline IV & No Phase Separation & No Phase Separation & No Phase Separation \\
\hline V & No Phase Separation & No Phase Separation & No Phase Separation \\
\hline \multicolumn{4}{|l|}{ Liquefaction } \\
\hline I & No Liquefaction & Slight Liquefaction & No Liquefaction \\
\hline II & No Liquefaction & Slight Liquefaction & No Liquefaction \\
\hline III & No Liquefaction & Slight Liquefaction & No Liquefaction \\
\hline IV & No Liquefaction & Slight Liquefaction & No Liquefaction \\
\hline V & No Liquefaction & Slight Liquefaction & No Liquefaction \\
\hline \multicolumn{4}{|l|}{ PH } \\
\hline I & 6.9 & 6.8 & 6.85 \\
\hline II & 6.5 & 6.45 & 6.5 \\
\hline III & 6.8 & 6.7 & 6.7 \\
\hline IV & 6.7 & 6.6 & 6.7 \\
\hline V & 7.2 & 7.0 & 7.2 \\
\hline \multicolumn{4}{|l|}{ Viscosity } \\
\hline I & 28450 & 28500 & 29954 \\
\hline II & 30620 & 30255 & 31075 \\
\hline III & 28500 & 28250 & 29000 \\
\hline IV & 30005 & 29875 & 30296 \\
\hline V & 32565 & 32158 & 33082 \\
\hline \multicolumn{4}{|l|}{ Spread ability } \\
\hline I & 20.55 & 20.08 & 17.09 \\
\hline II & 21.75 & 14.58 & 17.85 \\
\hline III & 19.49 & 19.05 & 17.04 \\
\hline IV & 20.05 & 19.25 & 17.35 \\
\hline V & 22.32 & 21.65 & 18.52 \\
\hline \multicolumn{4}{|l|}{ SPF } \\
\hline I & 12.25 & 12.34 & 10.84 \\
\hline II & 16.63 & 15.87 & 14.78 \\
\hline III & 24.05 & 22.62 & 20.57 \\
\hline IV & 12.84 & 10.35 & 10.46 \\
\hline V & 34.27 & 33.45 & 32.82 \\
\hline \multicolumn{4}{|l|}{ Extrudability } \\
\hline I & Fair & Fair & Fair \\
\hline II & Good & Good & Good \\
\hline III & Good & Good & Good \\
\hline IV & Excellent & Excellent & Good \\
\hline V & Excellent & Excellent & Excellent \\
\hline
\end{tabular}




\begin{tabular}{ccccccc}
\hline \multicolumn{7}{c}{ Centrifugation test for stability } \\
\hline Formulation & I & II & II & IV & V \\
\hline \multirow{2}{*}{ Observation } & No Phase & No Phase & No Phase & No Phase & No Phase \\
& Separation & Separation & Separation & Separation & Separation \\
Inference & Stable & Stable & Stable & Stable & Stable \\
\hline
\end{tabular}

ment of India. The cream was applied to the skin for 7 days and observed for any sensitivity ${ }^{19}$ and the reaction if any was graded as shown in Table 6.

Table 6: Grade of Sensitivity Reaction

\begin{tabular}{cc|}
\hline Sensitivity Reaction & Grade \\
\hline No reaction & A \\
Slight Patchy Erythema & B \\
Slight but confluent or moderate but patchy erythema & C \\
Severe Erythema with or without edema & D \\
\hline
\end{tabular}

The SPF of Formulation F-V found highest hence its skin irritation study was carried out. After 7 Days it was observed that, there was no any type of sensitivity reaction or irritation with erythema or edema. (Figure 8 ) The result is graded as - A (No Reaction).

\section{Total poly phenolic content determination}

Total polyphenolic compounds estimation in developed formulation can give idea of compatibility as well as total antioxidant potential responsible of each formulation. ${ }^{20}$ Folin-Ciocalteu method is most simple and accurate method in determination of total polyphenolic compounds. Estimation studies shown from standard calibration curve of gallic acid (Table 7 ) that highest phenolic content of $40.74 \%$ in formulation-F-V which can be expected due to combination of all four active in gredients of polyphenolic class. $22.07,21.89,25.67$ and $27.42 \%$ of total polyphenolic content of formulation F-I, F-II, F-III and F-IV are measured respectively.

Table 8: Results of standard calibration curve of gallic acid

\begin{tabular}{ccc}
\hline Standard & Absorbance $(765 \mathrm{~nm})$ & Concentration $(\mathrm{mg} / \mathrm{ml})$ \\
\hline 1 & 0.875 & 0.2 \\
2 & 1.698 & 0.4 \\
3 & 2.315 & 0.6 \\
4 & 2.667 & 0.8 \\
5 & 2.995 & 1.0 \\
\hline
\end{tabular}

\section{DETERMINATION SUN PROTECTION FACTOR (SPF)}

\section{In-vitro Determination Sun Protection Factor (SPF) by UV-spectrophotometer}

Sunlight despite of source of life and energy creating major health challenges like sunburn, pigmentation, wrinkles, dermatitis, urticaria, ageing, immune-suppression and number of skin cancers too. Sun protective clothes and or sunglasses provide insufficient and less convenient approach to get rid of all these health hazards. So sunscreen protection is popular mean among various regions of world. Efficacy of sunscreens is expressed in the form of Sunburn Protection Factor (SPF). The absolute protection performance of a sun care product against erythermal-effective UV radiation, calculated from the measured in vitro transmittance and weighted with the erythema action spectrum and with the "standard" output spectrum of a UV solar simulator used for SPF testing. SPF of active drugs, formulated creams, marketed sunscreen products and synthetic sunscreen agents were calculated by the application of equa-
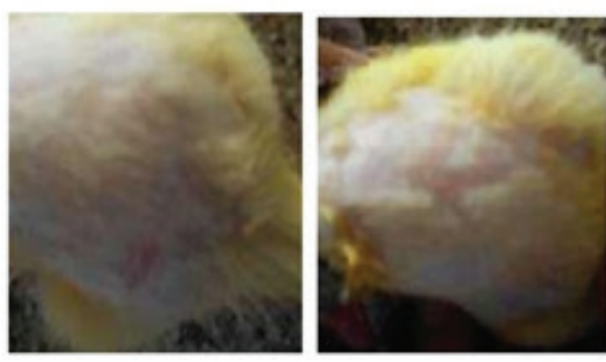

Control

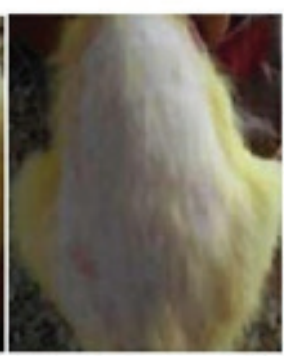

F-V applied
Figure 8: Skin irritation study by using rats.

tion. The aliquot prepared were scanned between $290-320 \mathrm{~nm}$ and the obtained absorbance values were multiplied with the respective $\mathrm{EE}(\lambda)$ and $I(\lambda)$ values. Then, their summation was taken and multiplied with the correction factor i.e. 10. All formulations i. e. FI (11.89), FII (16.11), FIII (23.10), FIV (12.35) and F-V (34.58) shows the significant SPF. (Table 9) SPF of synthetic sunscreen agents was found 22.40 for oxyben zone and 18 for avoben zone. The marketed formulations found with SPF 18.29 and 16.06 having lower SPF than label claims. The comparison with standard synthetic compounds and marketed herbal formulation shows promising results of developed formulation with higher SPF values. Combination of selected poly phenols in formulation F-V exhibited highest SPF value due to synergistic action. Resveratrol found to be more photo protective as compared to others. Efficacy of photo protection found: resveratrol > quercetin > safranal > curcumin. SPF of formulated phytochemicals found to be higher, which indicates synergism and compatibility of excipients too. These results reveal that the prepared formulations have good SPF and good sun protection activity.

\section{In-vitro Determination of SPF by UV 2000 S Ultraviolet Transmittance Analyzer (Lab sphere)}

The evaluation parameter of cream complies with the acceptance criteria and SPF of this cream found to be 22.60 indicates that the formulated cream can be considered as an efficient topical product. Statistical parameters are expressed in Table 10. The SPF graph report of topical herbal photo protective formulation is shown in Figure 9. Thus SPF of Formulation-V found highest when determined by UV-Spectrophotometer hence its SPF determined by UV- 2000S Ultraviolet Transmittance Analyzer. ${ }^{13,16}$ (KET’s Scientific Research Center, Mumbai)

The above readings are averages of 3 replicate each consisting of 6 scans. The Boots Guidelines for Star Rating: The Boots star rating is based on the average UVA/UVB ratio. A different rating is given to a range of values as shown below in Table 11. Rating levels differ for different wavelength sampling interval.

\section{CONCLUSION}

In present research work wound-healing curcumin, strong antioxidant quercetin, photo protective resveratrol and moisturizing as well as cooling safranal are incorporated together to develop efficient all-in-one sunscreen product. It is recommended that in detail studies of the safety, efficacy and toxicity of selected photo protectors are essential to establish product in market without any evidence of interactions.

\section{ACKNOWLEDGEMENT}

Nil 


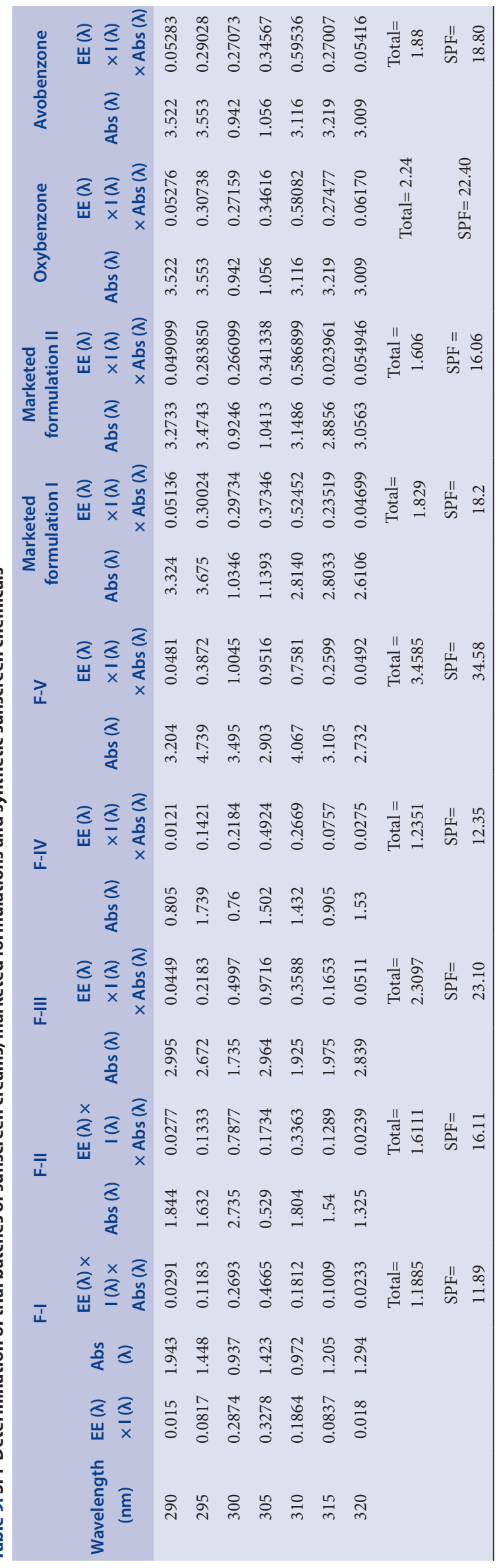

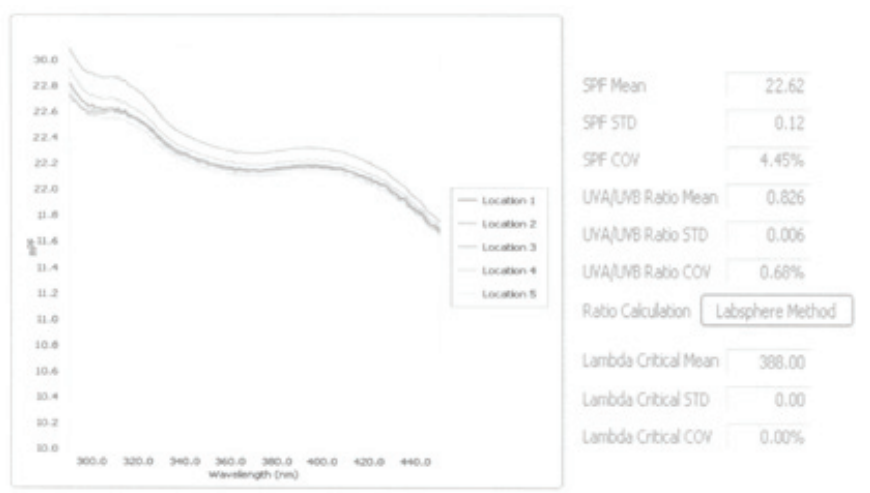

Figure 9: SPF Graph Report of Formulation F-V determined by UV- $2000 \mathrm{~S}$ Ultraviolet Transmittance Analyzer.

Table 10: Sun Protection Factor of Formulation-V by UV- 2000 S Ultraviolet Transmittance Analyzer

\begin{tabular}{|c|c|c|c|c|c|c|}
\hline No & Test Sample & $\begin{array}{c}\text { Scans } \\
\text { Parameters }\end{array}$ & 1 & 2 & 3 & $\begin{array}{c}\text { Average } \\
\text { Values }\end{array}$ \\
\hline 1 & \multirow{5}{*}{$\begin{array}{l}\text { Photo } \\
\text { Protective } \\
\text { Formulation }\end{array}$} & SPF & 21.56 & 22.63 & 22.62 & 22.60 \\
\hline 2 & & $\begin{array}{l}\text { Standard } \\
\text { Deviation }\end{array}$ & 0.09 & 0.12 & 0.12 & 0.11 \\
\hline 3 & & $\begin{array}{c}\text { UVA/UVB } \\
\text { Ratio }\end{array}$ & 0.825 & 0.823 & 0.826 & 0.825 \\
\hline 4 & & $\begin{array}{c}\text { Critical } \\
\text { Wavelength }\end{array}$ & 388.00 & 388.00 & 388.00 & 388.00 \\
\hline 5 & & $\begin{array}{c}\text { Boots Star } \\
\text { Rating }\end{array}$ & $* * *$ & $* * *$ & $* * *$ & $* * *$ \\
\hline
\end{tabular}

Table 11: The Boots Guidelines for Star Rating

\begin{tabular}{cc}
\hline Mean UVA/UVB ratio & Star Rating Category \\
\hline 0.0 to 0.59 & No Rating \\
0.6 to 0.79 & $* * *$ \\
0.8 to 0.9 & $* * * *$ \\
0.9 and over & $* * * * *$ \\
\hline
\end{tabular}

The study yielded a 22.60 Sun Protection Factor (SPF) and ${ }^{* * * *}$ Boots Star Rating as presented below following the application of the test samples on the transpore tape.

\section{CONFLICT OF INTEREST}

There is no conflict of interest. 


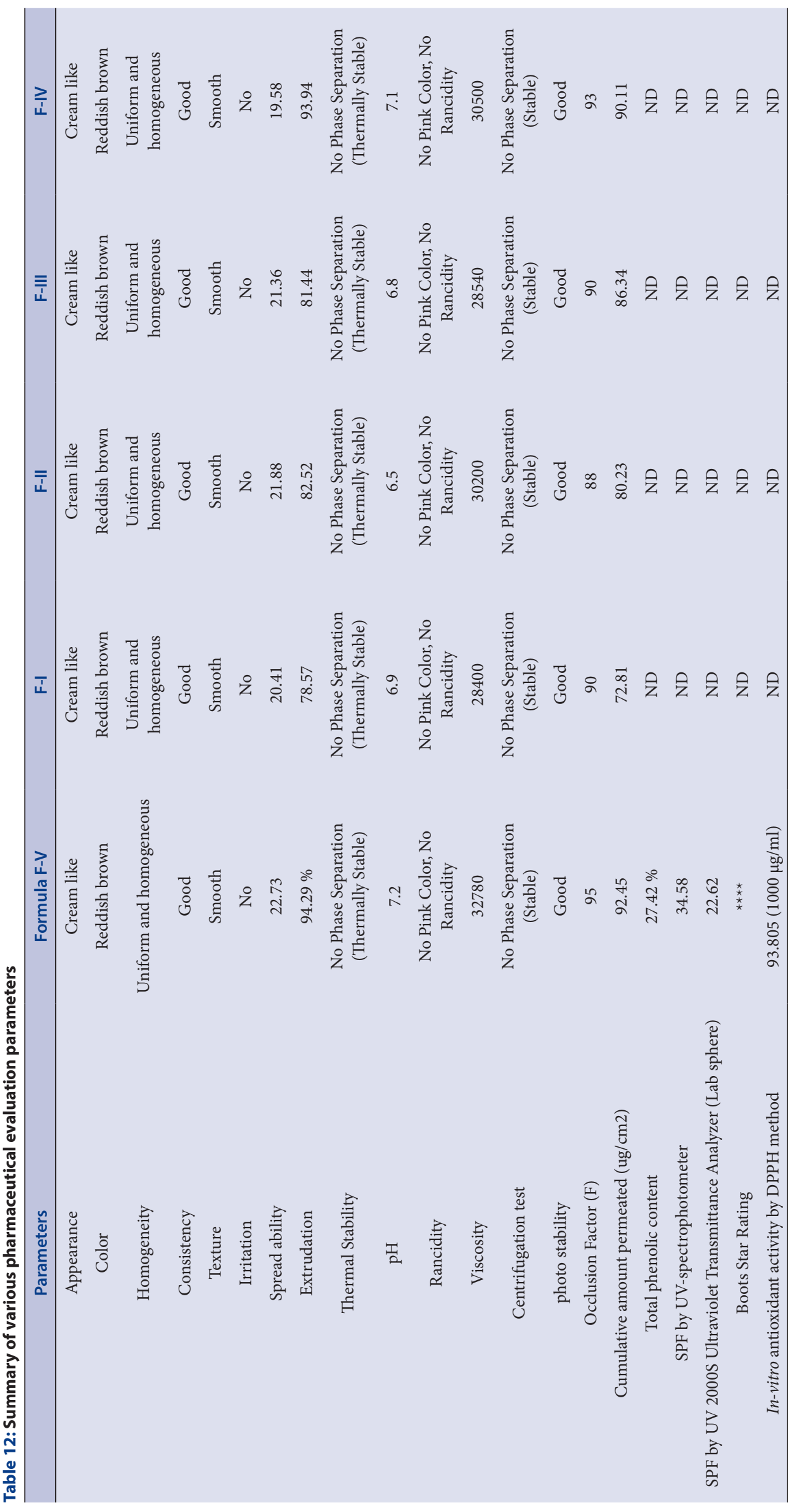




\section{REFERENCES}

1. Balogh TS, Velasco MV, Pedriali CA, Kaneko TM, Baby AR. Ultraviolet radiation protection: current available resources in photo protection. An Bras Dermatol. 2011;86(4):732-42.http://dx.doi.org/10.1590/S0365-05962011000 400016;PMid:21987140.

2. Skotarczak K, Osmola-Mankowska A, Lodyga M, Polanska A, Mazur M, Adamski Z. Photoprotection: facts and controversies. Eur Rev Med Pharmacol Sci. 2015;19(1):98-112.PMid:25635982.

3. Kaimal S, Abraham A. Sunscreens. Indian J Dermatol Venereol Leprol. 2011;77(2):238-43.http://dx.doi.org/10.4103/0378-6323.77480;PMid:21393968.

4. Saraf S, Kaur CD. Phytoconstituents as photo protective novel cosmetic formulations. Pharmacogn Rev. 2010;4(7):1-11.http://dx.doi.org/10.4103/09737847.65319;PMid:22228936 PMCid:PMC3249896.

5. Cho JW, Park K, Kweon GR, Jang BC, Baek WK, Suh MH, et al. Curcumin inhibits the expression of COX-2 in UVB-irradiated human keratinocytes ( $\mathrm{HaCaT}$ ) by inhibiting activation of AP-1: p38 MAP kinase and JNK as potential upstream targets. Exp Mol Med. 2005;30-37(3):186-92.

6. Choquenet B, Couteau C, Paparis E, Coiffard LJ. Quercetin and rutin as potential sunscreen agents: determination of efficacy by an in vitro method. J Nat Prod. 2008;71(6):1117-8. http://dx.doi.org/10.1021/np7007297;PMid:18512988.

7. DeRosa M, Rossi M. (2001). U.S. Patent Application No. 10/296,725.

8. Freitas JV, Praça FS, Bentley MV, Gaspar LR. Trans-resveratrol and betacarotene from sunscreens penetrate viable skin layers and reduce cutaneous penetration of UV-filters. Int J Pharm. 2015;484(1-2):131-7.

9. Golmohammadzadeh S, Jaffari MR, Hosseinzadeh H, Imani F. XML Determination of properties and evaluation of sun protective effects of saffron and safranal nanoliposomes. JDC. 2010;1(1):20-7.

10. Khameneh B, Halimi V, Jaafari MR, Golmohammedzadeh S. Safranal-loaded solid lipid nanoparticles: evaluation of sunscreen. Iran J Basic Med Sci. 2015;18(1):58-63. PMid:25810877 PMCid:PMC4366744.
11. Pavia D, Lampman G, Kriz G, Vyvyan J. Introduction to Spectroscopy. Fifth Edition, Cengage Learning, Stamford, USA PP.2014;14-86.

12. Wagner $H$, Bladt S. Plant drug analysis. A Thin layer chromatography Atlas. $2^{\text {nd }}$ edition. Springer-Verlag, Berlin, Heidelberg, New York.1996;32-52. PMid:8696384.

13. Sarruf FD, D'Almeida D. Assessment of in-vitro Sun Protection Factor (SPF) and rheological profile of commercial infant's sunscreens, $\mathrm{J}$ of Basic and Applied Pharamceutical Sciences. 2013;34(1):33-6.

14. Kasote DM, Katyare SS, Hegde MV, Bae H. Significance of antioxidant potential of plants and its relevance to therapeutic applications. Int J Biol Sci. 2015;11(8):982-91. http://dx.doi.org/10.7150/ijbs.12096;PMid:26157352 PMCid:PMC4495415.

15. Alam MN, Bristi NJ, Rafiquzzaman M. Review on in vivo and in vitro methods evaluation of antioxidant activity. Saudi Pharm J. 2013:21(2):143-52. http:// dx.doi.org/10.1016/j.jsps.2012.05.002;PMid:24936134 PMCid:PMC4052538.

16. Karthika P, Jayshree N. Formulation and evaluation of sunscreen cream containing flower extract of Delonixregia. IJOPILS. 2013;1(6):111-29.

17. Smaouia S, Hlimab HB, Chobbac IB, Kadric A. Development and stability studies of sunscreen cream formulations containing three photo-protective filters. Arabian Journal of Chemistry. 2013.http://dx.doi.org/10.1016/j.arabjc.2013.02.020.

18. Agrapidis Paloympis LE, Nash RA, Shaath NA. The effect of solvents on the ultraviolet absorbance of sunscreens. J Soc Cosmet Chem. 1987;38:209-21.

19. Silva DG, Daud F, Carolina SL. Influence of particle size on appearance and in-vitro efficacy of sunscreens. Brazilian $J$ of Pharmaceutical Science. 2013:49(2):251-61.http://dx.doi.org/10.1590/S1984-82502013000200007.

20. Khadabadi SS, Deore SL, Baviskar BA. Experimental. Phytopharmacognosy. $1^{\text {st }}$ ed. Nirali Prakashan. 2011;3(1):2-4.

21. Wissing SA, Muller RH. Solid lipid nano particles as carrier for sunscreens: in vitro release and in vivo skin penetration. J. Control Release. 2002;81(3):225-33. http://dx.doi.org/10.1016/S0168-3659(02)00056-1.

22. Lachman, Leon, Herbert A. Lieberman, and Joseph L. Kanig. The theory and practice of industrial pharmacy. Lea \& Febiger. 1986.

Cite this article: Donglikar MM, Deore SL. Development and Evaluation of Herbal Sunscreen Pharmacog J. 2017;9(1):83-97. 